\title{
Race and Gender Differences of Body Physique and Self-Esteem in High School Students
}

\author{
Jill E. Bennett ${ }^{1}$, Steven F. Philipp ${ }^{1}$, Petra B. Schuler ${ }^{1}$, Jane L. P. Roy ${ }^{2}$ \\ ${ }^{1}$ University of West Florida \\ ${ }^{2}$ University of Alabama at Birmingham
}

\begin{abstract}
This study investigated race and gender differences of body physique and self-esteem in high school students $(\mathrm{N}=754$, mean age $=16.5 \pm 1.2 \mathrm{yr})$ attending public schools. Participants completed a five part body physique questionnaire where responses were based on a set of nine figure silhouette drawings and a five part self esteem questionniare. African American females reported significantly larger body physique preferences when compared to their Caucasian counterparts $(\mathrm{p}<0.05)$; there was no significant difference between the Caucasian and African American males ( $p>0.05$ ). African American's (males and females) scored significantly higher on the self-esteem assessment than their Caucasian counterparts. These findings suggest that there might be important race and gender differences on various aspects of body physique and self-esteem in high school students.
\end{abstract}

(C)2007 Californian Journal of Health Promotion. All rights reserved.

Keywords: Body Shape, Race, Gender, Adolescents

\section{Introduction}

Among children and teenagers, obesity has become highly prevalent in the United States, with different rates found by gender and race. Recent estimates of body mass index (BMI) indicated that $10.5 \%$ of high school students are overweight, while $13.6 \%$ are at risk for becoming overweight (Grunbaum, Kann, Kinchen et al., 2002). Many overweight adolescents have reported that they are dissatisfied with their appearance and have low self esteem (Martin et al., 1988; Setiloane, 2004). Physically attractive individuals have been shown to have several advantages over less physically attractive individuals, including more desirable personalities, total happiness, success and social acceptance (Dion, Berscheid \& Walster, 1972). Adolescents are not immune to the sociocultural pressure from the media to be thin and to have an aesthetically pleasing appearance indicating that having a 'perfect body' is highly regarded in teenagers (Wiseman, Sunday and Becker, 2005; McCabe and Ricciardelli, 2005).

Early detection of body physique dissatisfaction and poor self esteem is extremely important in adolescents because of the emerging evidence that these individuals may engage in unhealthy behaviors such as excessive dietary restriction, use of appetite suppressants, laxatives, vomiting, binge eating and the development of eating disorders and body dysmorphic disorder (Stice, Cameron, Killen, Hayward, and Taylor, 2000). In addition obese teenagers are more likely to become obese adults which places them at higher risk for the development of a variety of adult clinical conditions such as cardiovascular disease, hypertension, diabetes mellitus and cancer (Freedman, Dietz, Scrinivasan, and Berenson, 1999; Killen et al., 1996; Stice, Cameron, Killen, Hayward, and Taylor, 1999; Whitaker, Wright, Pepe, Seidel, and Dietz, 1997). The purpose of this study was to investigate racial and gender differences in body physique perceptions and self esteem levels in high school students.

\section{Methods}

\section{Participants}

Six hundred and three (603) adolescent Caucasian and African American males and females (mean age $=16.5 \pm 1.2 \mathrm{yrs}$ ) enrolled in four public schools in Northwest Florida 
participated in this study [375 Caucasians (157 males, 218 females) and 228 African Americans (106 males, 122 females)]. Students were informed that their participation was voluntary and Institutional Review Board approved written consent was obtained prior to participation in the study. The students completed the questionnaires in a classroom setting during which researchers were present to answer questions if necessary. All data was collected during the spring semester (January - April). Participants were given as much time as they needed to complete the questionnaires.

\section{Questionnaires}

Body Physique Perceptions and Preferences. Using a set of nine figure silhouette drawings (Thompson and Gray, 1995) in which both genders were arranged ordinally from 1 (= very thin) to 9 (= very heavy) participants answered the following questions: 1) Which figure looks most like you?, 2) Which figure do you most want to look like?, 3) Which figure do you think that other people of your gender want to look like?, 4) Which figure do you think that the opposite sex finds the most attractive?, and 5) Which figure on the opposite sex's scale do you find the most attractive?
Self- esteem. Participants also completed a five part 'self-esteem' questionnaire that was scored on a Likert scale (from 1 = strongly disagree to 6 $=$ strongly agree) developed by the authors for the purpose of this study.

\section{Statistics}

Means, standard deviations and dependent t-tests were performed using SPSS software. Significance for all tests was set at $\mathrm{p}<0.05$.

\section{Results}

There were several differences $(\mathrm{p}<0.05)$ between race within gender for body physique characteristics (see Table 1). The Caucasian females chose significantly smaller female shapes $(p<0.05)$ than the African American females for questions $1-4$ (Which figure looks most like you? Which figure do you most want to look like? Which figure do you think that other people of your gender want to look like? Which figure do you think that the opposite sex finds the most attractive?'). For the males, the only significant race difference $(\mathrm{p}<0.05)$ was for question 5; African American males selected a significantly larger figure for their "most attractive" female.

Table 1

Means, standard deviations $(\mathrm{x}+\mathrm{SD})$ and t-tests of physique perception characteristics for race and gender

\begin{tabular}{|c|c|c|c|c|c|c|}
\hline $\begin{array}{c}\text { Physique } \\
\text { Perception } \\
\end{array}$ & $\begin{array}{c}\text { CA } \\
\text { Male }\end{array}$ & $\begin{array}{c}\text { AA } \\
\text { Male }\end{array}$ & $\begin{array}{c}\mathbf{P} \\
\text { value }\end{array}$ & CA Female & $\begin{array}{c}\text { AA } \\
\text { Female }\end{array}$ & $\begin{array}{c}\mathbf{p} \\
\text { value }\end{array}$ \\
\hline $\begin{array}{l}\text { 1. Which figure looks most } \\
\text { like you? }\end{array}$ & $\begin{array}{l}5.0 \pm 1.5 \\
(\mathrm{~N}=196)\end{array}$ & $\begin{array}{l}4.8 \pm 1.2 \\
(\mathrm{~N}=119)\end{array}$ & 0.18 & $\begin{array}{l}4.3 \pm 1.6 \\
(\mathrm{~N}=273)\end{array}$ & $\begin{array}{l}4.7 \pm 1.9 \\
(\mathrm{~N}=162)\end{array}$ & $0.03^{*}$ \\
\hline $\begin{array}{l}\text { 2. Which figure do you most } \\
\text { want to look like? }\end{array}$ & $\begin{array}{l}4.9 \pm 1.0 \\
(\mathrm{~N}=195)\end{array}$ & $\begin{array}{l}4.9 \pm 0.9 \\
(\mathrm{~N}=119)\end{array}$ & 0.99 & $\begin{array}{l}3.2 \pm 1.0 \\
(\mathrm{~N}=274)\end{array}$ & $\begin{array}{l}3.9 \pm 1.2 \\
(\mathrm{~N}=162)\end{array}$ & $<0.01^{*}$ \\
\hline $\begin{array}{l}\text { 3. Which figure do you think } \\
\text { that other people of your } \\
\text { own sex want to look like? }\end{array}$ & $\begin{array}{l}5.1 \pm 1.1 \\
(\mathrm{~N}=196)\end{array}$ & $\begin{array}{l}5.0 \pm 1.0 \\
(\mathrm{~N}=118)\end{array}$ & 0.33 & $\begin{array}{l}2.5 \pm 1.0 \\
(\mathrm{~N}=271)\end{array}$ & $\begin{array}{l}2.9 \pm 1.3 \\
(\mathrm{~N}=160)\end{array}$ & $<0.01^{*}$ \\
\hline $\begin{array}{l}\text { 4. Which figure do you think } \\
\text { that the opposite sex finds } \\
\text { the most attractive? }\end{array}$ & $\begin{array}{l}4.9 \pm 1.1 \\
(\mathrm{~N}=195)\end{array}$ & $\begin{array}{l}4.8 \pm 0.9 \\
(\mathrm{~N}=117)\end{array}$ & 0.43 & $\begin{array}{l}2.9 \pm 1.1 \\
(\mathrm{~N}=272)\end{array}$ & $\begin{array}{l}3.9 \pm 1.3 \\
(\mathrm{~N}=160)\end{array}$ & $<0.01^{*}$ \\
\hline $\begin{array}{l}\text { 5. Which figure on the } \\
\text { opposite sex's scale do } \\
\text { you find the most } \\
\text { attractive? }\end{array}$ & $\begin{array}{l}3.7 \pm 1.1 \\
(\mathrm{~N}=196)\end{array}$ & $\begin{array}{l}4.0 \pm 1.1 \\
(\mathrm{~N}=115)\end{array}$ & $0.01^{*}$ & $\begin{array}{l}4.7 \pm 1.0 \\
(\mathrm{~N}=274)\end{array}$ & $\begin{array}{l}4.8 \pm 1.0 \\
(N=162)\end{array}$ & 0.35 \\
\hline
\end{tabular}

* Significant difference between race within gender $(\mathrm{p} \leq 0.05)$. N.B. Questions 1-4 asked the participants to choose a figure that matched their own sex, and question 5 asked them to choose a figure from the opposite sex's scale. There was missing data for some of the questions due to omissions and illegible answers. 
African American males scored significantly higher than Caucasian males on four of the five self-esteem questions; they also had a more favorable score on the remaining question, "I am shy', yet the difference was not statistically significant $(\mathrm{p}=0.06)$. The African American females also showed significant favorable differences when compared to the Caucasian females on four of the five self-esteem questions; the only exception was "I am athletic" $(p=0.06)$ (see Table 2). Overall the African American male and female adolescents had higher self-esteem ratings than their Caucasian counterparts.

Table 2

Means, standard deviations $(x+S D)$ and t-tests of self esteem measures for race and gender

\begin{tabular}{|c|c|c|c|c|c|c|}
\hline $\begin{array}{c}\text { Self esteem } \\
\text { Measure }\end{array}$ & $\begin{array}{l}\text { CA } \\
\text { Male }\end{array}$ & $\begin{array}{l}\text { AA } \\
\text { Male }\end{array}$ & $\begin{array}{c}\mathbf{p} \\
\text { value }\end{array}$ & $\begin{array}{c}\text { CA } \\
\text { Female }\end{array}$ & $\begin{array}{c}\text { AA } \\
\text { Female }\end{array}$ & $\begin{array}{c}\mathbf{p} \\
\text { value }\end{array}$ \\
\hline I like myself & $\begin{array}{l}5.0 \pm 1.1 \\
(\mathrm{~N}=196)\end{array}$ & $\begin{array}{l}5.4 \pm 1.1 \\
(\mathrm{~N}=118)\end{array}$ & $<0.01^{*}$ & $\begin{array}{l}4.5 \pm 1.3 \\
(\mathrm{~N}=272)\end{array}$ & $\begin{array}{l}5.2 \pm 1.2 \\
(\mathrm{~N}=164)\end{array}$ & $<0.01^{*}$ \\
\hline $\begin{array}{l}\text { I care about what other } \\
\text { people think of me }\end{array}$ & $\begin{array}{l}3.7 \pm 1.7 \\
(\mathrm{~N}=196)\end{array}$ & $\begin{array}{l}2.8 \pm 1.8 \\
(\mathrm{~N}=116)\end{array}$ & $<0.01^{*}$ & $\begin{array}{l}4.0 \pm 1.5 \\
(\mathrm{~N}=274)\end{array}$ & $\begin{array}{l}2.9 \pm 1.7 \\
(\mathrm{~N}=164)\end{array}$ & $<0.01^{*}$ \\
\hline $\begin{array}{l}\text { I wish that I was better } \\
\text { looking }\end{array}$ & $\begin{array}{l}3.6 \pm 1.6 \\
(\mathrm{~N}=196)\end{array}$ & $\begin{array}{l}2.7 \pm 1.7 \\
(\mathrm{~N}=115)\end{array}$ & $<0.01^{*}$ & $\begin{array}{l}4.2 \pm 1.5 \\
(\mathrm{~N}=271)\end{array}$ & $\begin{array}{l}2.7 \pm 1.8 \\
(\mathrm{~N}=163)\end{array}$ & $<0.01^{*}$ \\
\hline I am shy & $\begin{array}{l}3.0 \pm 1.7 \\
(\mathrm{~N}=196)\end{array}$ & $\begin{array}{l}2.7 \pm 1.6 \\
(\mathrm{~N}=117)\end{array}$ & 0.06 & $\begin{array}{l}2.9+1.7 \\
(\mathrm{~N}=274)\end{array}$ & $\begin{array}{l}3.3 \pm 1.8 \\
(\mathrm{~N}=164)\end{array}$ & $0.03^{*}$ \\
\hline
\end{tabular}

* Significant difference between race within gender $(\mathrm{p} \leq 0.05)$

N.B: ordinal ratings on a 6 point Likert scale, from $1=$ strongly disagree to $6=$ strongly agree. Italic font indicates a significantly 'more favorable' response within gender. There was missing data for some of the questions due to omissions and illegible answers.

\section{Discussion}

This study supports earlier research that the African American female adolescents perceive themselves as heavier (Russell et al., 2001), prefer a larger body shape (Sobal, 1995) and have higher self-esteem (Setiloane, 2004) than their Caucasian counterparts indicating that race is a strong determinant of body physique preference and perception (Sobal, 1995). The higher body weight acceptance by the African American females may be influenced by the fact that African American males appeared to prefer a larger female body figure than their Caucasian counterparts. The preference for a heavier body type and higher self-esteem among African American females may serve as protective factor against body image dissatisfaction, but it may fail to serve as a protective factor against obesity (Parnell et al., 1996). The Caucasian females who reported a lower self-esteem and lower body physique perceptions and preferences, may be at an increased risk for developing an eating disorder but at a reduced risk for being overweight (Fisher, 1990).

The findings of this study support prior research (Story, French, Resnick, and Blum, 1995) suggesting that African American females are less likely to perceive themselves as overweight, feel prouder of and tend to be more accepting of their own bodies. In the present study, the African American and Caucasian males had similar body physique perceptions and preferences, but the African American males scored significantly higher on most of the selfesteem questions. The findings suggest that important racial and gender differences exist on various aspects of body physique and selfesteem. The observed tendency to desire smaller body shapes in Caucasian females might put them at a greater risk for dieting and disordered eating, whereas the preference and acceptance of larger body shapes in African American females might increase their risk for becoming 
overweight or obese. In conclusion, school healthcare educators/providers should be aware of these gender and racial differences in selfesteem and body physique perceptions and preferences when implementing weight management and eating disorder program interventions with adolescents.

\section{References}

Dion, K., Berscheid, E., \& Walster, E. (1972). What is beautiful is good. Journal of Personality and Social Psychology, 24, 285-290.

Fisher, S. (1990). The evolution of psycholgical concepts about the body. In T. F. Cash and T. Pruzinsky (Eds.), Body images: Development, deviance, and changes (pp. 3-20). New York: Guildford Press.

Freedman, D., Dietz, W., Scrinivasan, S., \& Berenson, G. (1999). The relation of overweight to cardiovascular risk factors among children and adolescents: The Bogalusa Heart Study. Pediatrics, 103, 1175-1182.

Grunbaum, J., Kann, L., Kinchen, S., Ross, J., Hawkins, J., Lowry, R. et al. (2004). Youth risk behavior surveillance - United States, 2003. MMWR Surveillance Summary, 28, 1-62.

Killen, J. D., Taylor, C. B., Hayward, C., Haydel, K. F., Wilson, D. M., Hammer, L. D., et al. (1996). Weight concerns influence the development of eating disorders: A 4-year prospective study. Journal of Consulting and Clinical Psychology, 64, 936-940.

Martin, S., Houseley, K., McCoy, H., Greenhouse, P., Stigger, F., \& Kenney, M. A., et al. (1988). Self esteem of adolescent girls as related to weight. Perceptual and Motor Skills, 67, 879-884.

McCabe, M. P., \& Ricciardelli, L. A. (2005). A prospective study of pressures from parents, peers, and the media on extreme weight change behaviors among adolescent boys and girls. Behaviour Research and Therapy, 43, 653-668.

Parnell, K., Sargent, R., Thompson, S., Duhe, S., Valois, R., \& Kemper, R. (1996). Black and white adolescent females' perceptions of ideal body size. Journal of School Health, 66, 112-118.

Russell, D. L., Keil, M. F., Bonat, S. H., Uwaifo, G. I., Nicholson, J. C., \& McDuffie, J. R. (2001). The relation between skeletal maturation and adiposity in African American and Caucasian children. Journal of Pediatrics, 139, 844-848.

Setiloane, K. (2004). Being overweight: Negative outcomes for African American adolescents. Nutrition and Health, 18, 61-66.

Sobal, J. (1995). Social influences on body weight. In K. D. Brownell \& C. F. Fairburn (Eds.), Eating disorders and obesity: A comprehensive handbook (pp.73-77). New York: Guildford Press.

Stice, E., Cameron, R., Killen, J., Hayward, C., \& Taylor, C. B. (1999). Naturalistic weight-reduction efforts prospectively predict growth in relative weight and onset of obesity among female adolescents. Journal of Consulting and Clinical Psychology, 67, 967-974.

Stice, E., Hayward, C., Cameron, R., Killen, J., \& Taylor, C. (2000). Body image and eating disturbances predict onset of depression among female adolescents: A longitudinal study. Journal of Abnormal Psychology, 109, 438-444.

Story, M., French, S. A., Resnick, M. D., \& Blum, R. W. (1995). Ethnic/racial and socioeconomic differences in dieting behaviors and body image perceptions in adolescents. International Journal of Eating Disorders, 18, 173-179.

Thompson, M. A., \& Gray, J. J. (1995). Development and validation of a new body image assessment scale. Journal of Personality Assessment, 64, 263.

Thompson, S. H., Corwin, S. J., \& Sargent, R. G. (1997). Ideal body size beliefs and weight concerns of fourth-grade children. International Journal of Eating Disorders, 21, 279-284.

Whitaker, R. C., Wright, J. A., Pepe, M. S., Seidel, K. D., \& Dietz, W. H. (1997). Predicting obesity in young adulthood from childhood and parental obesity. New England Journal Medicine, 337, 869873.

Wiseman, C. V., Sunday, S. R., \& Becker, A. E. (2005). Impact of the media on adolescent body image. Child and Adolescent Psychiatrics Clinics of North America, 14, 453-471. 


\section{Acknowledgements}

Ms. Jill Bennett was a first-year graduate student in the exercise science program, and the data were collected as part of a class project. The supervising faculty member was Dr. Steven F. Philipp.

\section{$\underline{\text { Author Information }}$}

Jill E. Bennett, BS*

University of West Florida

Ph.: 850-474-2596

Fax.: 850-474-2106

E-Mail: jec34@students.uwf.edu

Steven F. Philipp, $\mathrm{PhD*}$

University of West Florida

Ph.: 850-474-2597

Fax.: 850-474-2106

E-Mail: sphilipp@uwf.edu

Petra B. Schuler

University of West Florida

Jane L. P. Roy

University of Alabama at Birmingham

* corresponding author 